\title{
Prevalence of liver condemnation due to bovine fasciolosis in Southern Espírito Santo: temporal distribution and economic losses
}

\author{
Prevalência de condenação de fígados bovinos por fasciolose no Sul do Espírito Santo: \\ distribuição temporal e perdas econômicas \\ Cíntia das Chagas Bernardo ${ }^{1}$; Milena Batista Carneiro ${ }^{1}$; Barbara Rauta de Avelar ${ }^{1}$; Dirlei Molinari Donatele ${ }^{2}$; \\ Isabella Vilhena Freire Martins ${ }^{2 *}$; Maria Julia Salim Pereira ${ }^{3}$ \\ ${ }^{1}$ Laboratório de Parasitologia, Centro de Ciências Agrárias, Universidade Federal do Espírito Santo - UFES \\ ${ }^{2}$ Departamento de Medicina Veterinária, Centro de Ciências Agrárias, Universidade Federal do Espírito Santo - UFES \\ ${ }^{3}$ Departamento de Parasitologia Animal, Universidade Federal Rural do Rio de Janeiro - UFRRJ
}

Received October 14, 2010

Accepted February 1, 2011

\begin{abstract}
The present study was conducted to evaluate the economic losses and temporal distribution of the prevalence of liver condemnation due to bovine fasciolosis. The abattoir in Atílio Vivácqua, in the South of the State of Espírito Santo, which is under state inspection by the veterinary service of the Livestock and Forest Protection Institute of Espírito Santo, was used as the data source. The prevalence of liver condemnation due to fasciolosis over the period 2006-2009 was calculated. The $\chi^{2}$ test, simple linear regression analysis and $\chi^{2}$ for trend were used, with a significance level of $\mathrm{p} \leq 0.05$. Over the period analyzed, 110,956 cattle were slaughtered and the prevalence of liver condemnation due to Fasciola hepatica was 15.24\% in 2006, 23.93\% in 2007, 28.57\% in 2008 and 28.24\% in 2009. The historical trend of liver condemnation is an increasing trend, thus indicating that this parasitism has become established in the herd as a problem in this region, with prevalence similar to that of traditionally endemic regions. Condemnations occurred throughout the year, with the highest prevalence in April and May and with significant differences between the dry and wet seasons. The economic losses from liver condemnation can be considered high.
\end{abstract}

Keywords: Fasciola hepatica, abattoir, prevalence.

\section{Resumo}

O presente trabalho foi realizado com o objetivo de avaliar as perdas econômicas e a distribuição temporal da prevalência de condenação de fígados bovinos devido a fasciolose. $\mathrm{O}$ matadouro frigorífico de Atílio Vivácqua, no sul do Estado do Espírito Santo, com inspeção estadual, realizada por médico veterinário vinculado ao Instituto de Defesa Agropecuária e Florestal do Espírito Santo, foi utilizado como fonte de dados. A prevalência de condenaçáo de fígados por fasciolose no período de 2006-2009 foi calculada. O teste do $\chi^{2}$, a análise de regressão linear simples e o $\chi^{2}$ para tendência foram utilizados, considerando-se o nível de significância $\mathrm{p} \leq 0,05$. No período analisado foram abatidos 110.956 bovinos, observando-se prevalências de condenação de fígados por Fasciola hepatica, de 15,24\% em 2006, $23,93 \%$ em 2007, 28,57\% em 2008 e de 28,24\% em 2009. A tendência histórica da condenação de fígados é crescente, indicando que este parasitismo estabeleceu-se no rebanho como um problema na região com prevalência similar a de regiôes tradicionalmente endêmicas. As condenaçóes ocorreram o ano todo com maior prevalência nos meses de abril e maio e com diferenças significativas entre os períodos seco e chuvoso. As perdas econômicas devido a condenação de fígados podem ser consideradas altas.

Palavras-chave: Fasciola hepatica, matadouro frigorífico, prevalência.

\footnotetext{
*Corresponding author: Isabella Vilhena Freire Martins

Departamento de Medicina Veterinária, Centro de Ciências Agrárias,

Universidade Federal do Espírito Santo - UFES, Alto Universitário,

CP 16, CEP 29500-000, Centro, Alegre - ES, Brazil;

e-mail: ivfmartins@yahoo.com.br
} 


\section{Introduction}

Hepatic distomatosis or fasciolosis is a parasitic disease affecting herbivorous mammals and humans that is caused by the trematode Fasciola hepatica (BOWMAN, 2010). Currently, fasciolosis is recognized as an emerging zoonosis. The records of natural infection in humans are mostly correlated with regions that are endemic for animal fasciolosis, in rural communities in which humans share the water source with their animals, or areas in which raw vegetables cultivated in endemic regions are consumed (ROBINSON; DALTON, 2009).

Fasciolosis causes serious losses to cattle and sheep rearing through reducing herd productivity in terms of inhibition of growth, smaller weight gains and diminished milk production. In addition, it leads of condemnation of the animals' livers and increases the production costs because of the control measures required (OAKLEY et al., 1979; DAEMON; SERRA-FREIRE, 1992).

The distribution of fasciolosis is linked to climatic factors, management of reservoir animals, topographic factors and presence in the environment of molluscs of the genus Lymnaea, which are needed for the parasite's life cycle to be completed (MATTOS et al., 1997).

In Brazil, parasitism due to $F$. hepatica was traditionally recorded in the Southern and Southeastern regions (RESENDE, 1979 apud AMATO et al., 1986). However, its occurrence differs from the coverage of endemic regions, which are extensive in states in the Southern region and present less extensive foci in states in the Southeastern and central-western regions (LIMA et al., 2009).

According to Serra-Freire et al. (1995), the State of Espírito Santo was not known to be an endemic area for fasciolosis. However, according to reports from Fraga (2008), fasciolosis started to appear in the South of the State of Espírito Santo from 1995 onwards, in the Soturno area of the municipality of Cachoeiro de Itapemirim, in cattle slaughtered in the municipal abattoir, but without inspection. The first cases recorded by the Livestock and Forest Protection Institute of Espírito Santo only appeared in 2005. However, the temporal distribution of bovine fasciolosis is still unknown. Nor is there any estimate of the economic losses caused by liver condemnation in this region.

Thus, knowledge of the temporal distribution of fasciolosis in the South of the State of Espírito Santo becomes important not only for better understanding of this disease but also for planning control actions, given that time series analysis on events within populations may generate information for indicating risks, monitoring their spread and preventing their occurrence, thereby providing clues towards explaining the causes and support for implementing preventive measures and assessing the impact of such interventions (MEDRONHO et al., 2002). Data from abattoirs have been used to study the prevalence of liver condemnation by some authors (FRAGA, 2008; BAPTISTA, 2008), but no time series analysis was conducted in any of these studies. Such analysis is used within epidemiology to detect the temporal trends of health events (THRUSFIELD, 2004). In addition, abattoirs have a sentinel role, and data thus generated may serve to enable herd tracking within the scope of disease control programs (BAPTISTA et al., 2004).
The present study was carried out with the aim of assessing the economic losses and temporal distribution of the prevalence of condemnation of bovine livers due to fasciolosis in the South of the State of Espírito Santo, using an abattoir in that region as the data source.

\section{Material and Methods}

The abattoir in the municipality of Atílio Vivácqua, which is located in the Southern region of Espírito Santo, was used as the source of data. This region is composed of 22 municipalities and has a high-altitude tropical climate, with large variations in altitude and relief consisting of plains and mountainous zones cut by numerous watercourses that rise in this region because of its high rainfall. Coffee cultivation and dairy farming are the predominant types of agricultural activity, and the cattle population has been estimated to be 452,807 animals, with milk productivity of 1037 liters/cow/year (IBGE, 2008).

The figures for liver condemnation and cattle slaughtered at this abattoir over the period from January 2006 to December 2009 were analyzed. According to information contained in animal transit records, the animals slaughtered came from municipalities in the South of the State of Espírito Santo. The abattoir is under state inspection by the veterinary service of the Livestock and Forest Protection Institute of Espírito Santo and condemnation due to fasciolosis is implemented in accordance with article 148 of the state regulations for prior industrial and sanitary inspection and supervision for products of animal origin (IDAF, 2010).

The $\chi^{2}$ test for trend was used to assess associations between prevalence and the study year, and simple linear regression was used to obtain the straight line for the prevalence trend. To calculate the prevalence, the number of livers condemned was divided by the total number of heads of cattle slaughtered, and the result was multiplied by 100 . The months of the year were divided into two periods, i.e. the dry season (April to September) and the wet season (October to March), and the $\chi^{2}$ test was applied to investigate associations between prevalence and season. The monthly oscillation was analyzed graphically, as plots of the mean monthly prevalence over the periods evaluated.

To estimate the economic losses, the weight of the liver was taken to be $4.7 \mathrm{~kg}$ and value per kilogram was taken to be $\mathrm{R} \$ 5.00$. To convert the price into dollars, the exchange rate was taken to be US\$1.00 = R $\$ 1.70$.

\section{Results and Discussion}

Between 2006 and 2009, 110,956 heads of cattle were slaughtered at the abattoir in the municipality of Atílio Vivácqua, in the South of the State of Espírito Santo. Out of this total, 27,625 livers were condemned due to hepatic fasciolosis, thus representing prevalence of $24.89 \%$. Similar results have been reported from the Southern region of Brazil, which has traditionally presented areas endemic for fasciolosis (DUTRA et al., 2010). In Table 1, it can be seen that the numbers of liver condemned were significantly different between the years. It needs to be emphasized that because all the animals came from the South of the State of 
Espírito Santo, and because of the confirmed presence of Lymnaea columella (ALMEIDA, 2010) and infected animals, through feces examination at farms in several municipalities (ALVES, 2010), the disease has become established in this region.

In Figure 1, it can be seen that the straight-line trend of liver condemnations due to fasciolosis is an increasing trend. In Rio Grande do Sul, where the problem is more long-standing, Marques and Scroferneker (2003) reported a small reduction in condemnations of bovine livers due to infection by $F$. hepatica. Moreover, in an analysis on data relating to slaughtering of sheep in abattoirs under supervision by the federal inspection service in Rio Grande do Sul, between 2000 and 2005, Cunha et al. (2007) observed that the percentage condemnation of livers decreased. Since fasciolosis in sheep is more serious than in cattle, and because Rio Grande do Sul has been known as an endemic area for a long time, it can be expected that producers' knowledge about this parasitism will be greater. This would consequently lead to more effective control in this region, thus explaining the decrease in liver condemnation observed. Although studies on historical trends among health events are important for assessing the impact of control measures (MEDRONHO et al., 2002), there are no reports in the literature on this type of study for analyzing fasciolosis control. The results from the present study indicate that control measures in Espírito Santo either are not being implemented or are not being implemented efficiently. This situation may have arisen because livestock farmers may not have perceived the economic losses caused by fasciolosis, given that the payments that they receive are for the carcass weight (BAPTISTA, 2008), independent of organ condemnation. On the

Table 1. Prevalence of liver condemnation due to Fasciola hepatica in cattle slaughtered at the abattoir in the municipality of Atílio Vivácqua, Espírito Santo, between 2006 and 2009.

\begin{tabular}{ccccc}
\cline { 1 - 3 } Year & $\begin{array}{c}\text { Total number of heads } \\
\text { of cattle slaughtered }\end{array}$ & \multicolumn{2}{c}{$\begin{array}{c}\text { Prevalence of } \\
\text { condemned livers }\end{array}$} & \multirow{2}{*}{ OR* $^{*}$} \\
\cline { 3 - 4 } & & $\mathbf{N}$ & \% & \\
\hline 2006 & 20425 & 3114 & 15.24 & 1.00 \\
2007 & 26882 & 6434 & 23.93 & 1.75 \\
2008 & 29779 & 8509 & 28.57 & 2.22 \\
2009 & 33870 & 9568 & 28.24 & 2.19 \\
\hline
\end{tabular}

$\chi^{2}$ for trend $=1152.85 ; \mathrm{p} \leq 0.05$; ${ }^{*}$ Odds Ratio

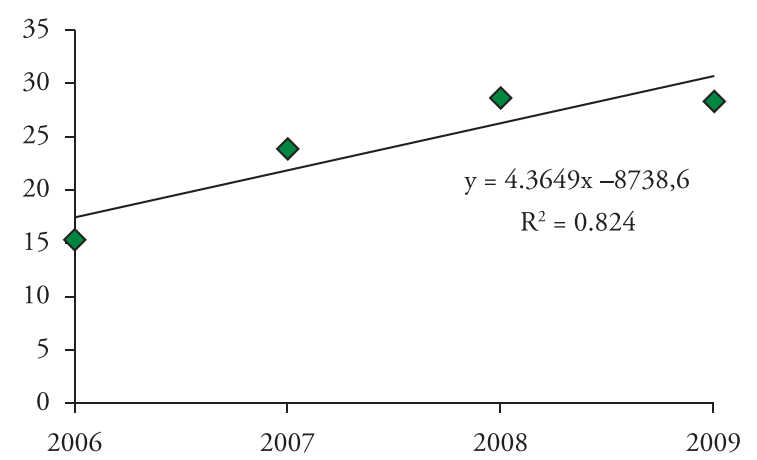

Figure 1. Trend for condemnation of cattle liver due to hepatic fasciolosis at the abattoir in the municipality of Atílio Vivácqua, Southern region of the State of Espírito Santo, between 2006 and 2009. other hand, subclinical infections may not have been noticed by livestock farmers, which may have led them not to consider that fasciolosis is a problem. According to Baptista (2008), in 2007, the prevalence of liver condemnation due to fasciolosis in 12 abattoirs under state inspection in Espírito Santo was 4.88\%, out of a total of 134,356 animals slaughtered, with $80 \%$ of the condemnations occurring at the abattoir in Atílio Vivácqua. Thus, it was found that parasitism had become established in the herd as a problem in this region, with prevalence similar to that of endemic regions.

In the present study, liver condemnations occurred throughout the year, but with highest prevalence in April and May, i.e. autumn in Brazil (Figure 2), and significantly greater prevalence during the dry season (April to September) than in the wet season (Table 2). During the dry season of the year, animals have access to vegetation in areas that were flooded during the wet season. Amato et al. (1986) reported that the population density of Lymnaea columella in the valley of the Paraíba river decreased from September to February and increased from March to September. They also observed that the greatest numbers of metacercariae occurred on pasture land between June and October and between March and April. In Itajubá, State of Minas Gerais, Coelho and Lima (2003) observed that the floods reduced the population of L. columella, since the intense water flow removed most of the molluscs from the area. Also in Itajubá, Faria et al.(2005) observed that elimination of $F$. hepatica eggs by cattle occurred throughout the year, but increased during the months of least precipitation (dry season), with a peak in September. They raised the hypothesis that the population of $L$. columella would increase during these months, thereby increasing the quantity of metacercariae ingested by the

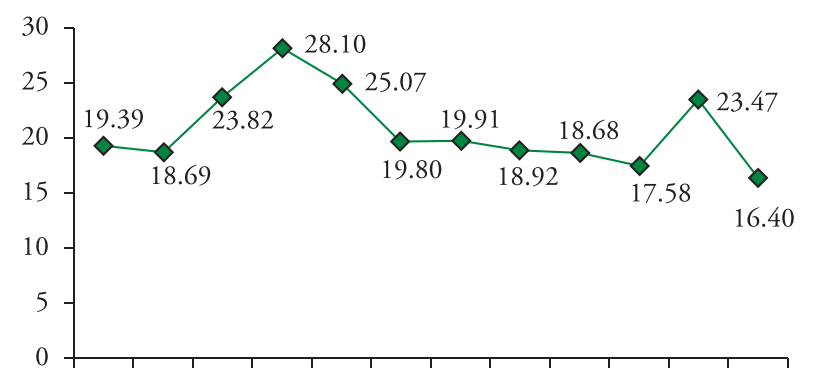

Jan. Feb. Mar. Apr. May June July Aug. Sep. Oct. Nov. Dec.

Figure 2. Mean monthly prevalence of condemnation of cattle liver due to hepatic fasciolosis at the abattoir in the municipality of Atílio Vivácqua, Southern region of the State of Espírito Santo, between 2006 and 2009.

Table 2. Prevalence of condemnation of cattle liver due to hepatic fasciolosis at the abattoir in the municipality of Atílio Vivácqua, Southern region of the State of Espírito Santo, between 2006 and 2009.

\begin{tabular}{cccc}
\hline Season & Number of cattle & \multicolumn{2}{c}{ Liver condemnation } \\
\cline { 3 - 4 } & slaughtered & N & \% \\
\hline Dry (April to September) & 43920 & 15265 & 25.79 \\
Wet (October to March) & 39411 & 12360 & 23.87 \\
\hline
\end{tabular}

$\chi^{2}=108.01 ; \mathrm{p}<0.01$ 
cattle. This may also have occurred in the region of the present study. Although no studies on the dynamics of fasciolosis or Lymnaea in Espírito Santo are yet available, the results from the present study are coherent with the biological cycle of the parasite, which has a prepatent period in cattle of 10 to 11 weeks. After definitively infecting the host, the immature forms reach the liver within six days and migrate to it over a six to seven-week period, attaining the adult stage after two months (FREITAS, 1977). Thus, two weeks after the time of infected was sufficient time for the animals to present lesions in the hepatic parenchyma, thus resulting in condemnation of this organ.

Between 2006 and 2009, the economic loss caused by condemnation of livers parasitized with $F$. hepatica that were found at the abattoir in the municipality of Atílio Vivácqua was R\$ 649,187.50, which corresponds to 381,875 US dollars. In the year 2009 alone, the losses were approximately 132,000 dollars, and this amount can be considered to be high, given that Echevarria (1995) found that the annual loss due to condemned livers in Rio Grande do Sul reached 140,000 dollars, in a state with a herd that is much larger than that of Espírito Santo.

Thus, fasciolosis is currently a severe economic problem for producers in the Southern region of Espírito Santo and possibly for the whole territory of the state, given the possibility of dissemination to herds of cattle, sheep, goats and buffalos in many municipalities through transportation of parasitized animals and through the presence of intermediate hosts in different hydrographic basins in the region.

\section{Conclusion}

The historical trend of liver condemnation due to fasciolosis found in slaughtered cattle at an abattoir in the South of the State of Espírito Santo was an increasing trend, with significant differences between the dry and wet seasons, thus indicating that this parasitism had become established in the herd as a problem in this region, with prevalence similar to that of traditionally endemic regions, and that the control measures were inefficient. The economic losses caused by liver condemnation could be considered to be high.

\section{Acknowledgements}

To the veterinarians at IDAF and ABAV for supplying slaughter data and to Capes for financial assistance (Procad project no. 093/2007).

\section{References}

ALMEIDA, B. R. Malacologia dos gêneros Lymnaea e Biomphalaria na mesorregiáo sul Espírito-Santense, e avaliaçáo de extratos de Melia azedarach, Azadirachta indica e Cymbopogon winterianus como agentes moluscicidas. 2010. 171 f. Dissertação (Mestrado em Ciências Veterinárias) - Universidade Federal do Espírito Santo. Disponível em: <http://www.dominiopublico.gov.br/download/texto/cp144525.pdf>. Acesso em: 16 jan. 2011.
ALVES, D. P. Distribuiçáa e fatores associados à infecçáo por Fasciola hepatica em bovinos em municípios do Sul do Estado do Espírito Santo no período de 2008/2009. 2010. 76 f. Dissertaçáo (Mestrado em Ciências Veterinárias) - Universidade Federal do Espírito Santo. Disponível em: <http://www.dominiopublico.gov.br/download/texto/ cp143849.pdf >. Acesso em: 16 jan. 2011.

AMATO, S. B. et al. Epidemiology of Fasciola hepatica infection in the Paraíba river valley, São Paulo, Brasil. Veterinary Parasitology, v. 22, n. 3-4, p. 275-284, 1986.

BAPTISTA, A. T. Quantificaçóes das condenaçóes em vísceras de bovinos em 2007 nos matadouros-frigoríficos do estado do Espírito Santo registrados no serviço de inspeçáo estadual. 2008. $14 \mathrm{f}$. Trabalho de conclusão de curso (Especialização em Higiene e Inspeção de Produtos de Origem Animal) - Universidade Castelo Branco. Disponível em: $<$ http://www.qualittas.com.br/documentos/Quantificacoes\%20das\%20 Condenacoes \%20-\%20Anderson\%20Teixeira\%20Baptista.pdf> Acesso em: 13 ago. 2010.

BAPTISTA, F. et al. Prevalência da tuberculose em bovinos abatidos em Minas Gerais. Arquivo Brasileiro de Medicina Veterinária e Zootecnia v. 56, n. 5, p. 577-580, 2004.

BOWMAN, D. D. Georgis - Parasitologia Veterinária. 9. ed. Rio de Janeiro: Elsevier, 2010. 432 p.

COELHO, L. H. L.; LIMA, W. S. Population dynamics of Lymnaea columella and its natural infection by Fasciola hepatica in the State of Minas Gerais, Brazil. Journal of Helminthology, v. 77, n. 1, p. 7-10, 2003.

CUNHA, F. O. V.; MARQUES, S. M. T.; MATTOS, T. M. J. Prevalence of slaughter and liver condemnation due to Fasciola hepatica among sheep in the state of Rio Grande do Sul, Brazil 2000 and 2005. Parasitologia Latinoamericana, v. 62, n. 3-4, p. 188-191, 2007.

DAEMON, E.; SERRA-FREIRE, N. M. Estudos da relaçấo custobenefício em parasitologia: uma proposta de análise. Parasitologia al Día, v. 16, p. 59-62, 1992.

DUTRA, L. H. et al. Mapping risk of bovine fasciolosis in the south of Brazil using Geographic Information Systems. Veterinary Parasitology, v. 169, n. 1-2, p. 76-81, 2010.

ECHEVARRIA, F. A. M. Mesa redonda sobre fasciolose bovina. Hora Veterinária, n. 1, p. 27-31, 1995. Ed. Extra.

FARIA, R. N.; CURY, M. C.; LIMA, W. S. Prevalence and dynamics of natural infection with Fasciola hepatica (Linnaeus, 1758) in Brazilian cattles. Revue Médicine Véterinaire, v. 156, n. 2, p. 85-86, 2005.

FRAGA, J. C. L. Incidência da Fasciolose Hepática Bovina no Sul do Espírito Santo. 2008. 29 f. Trabalho de conclusão de curso (Especialização) - Instituto Brasileiro de Pós-Graduação Qualittas, Universidade Castelo Branco, Rio de Janeiro. Disponível em: <http:// www.qualittas.com.br/documentos/Incidencia $\% 20 \mathrm{da} \% 20$ Fasciolose $\% 20$ Hepatica\%20Bovina\%20no\%20Sul\%20-\%20Jose\%20Carlos\%20 Landeiro\%20Fraga.PDF>. Acesso em: 25 jul. 2010.

FREITAS, M. G. Helmintologia veterinária. 3. ed. Belo Horizonte: Rabelo \& Brasil, 1977. 396 p.

INSTITUTO BRASILEIRO DE GEOGRAFIA E ESTATÍSTICA IBGE. Produçáo pecuária Municipal. 2008. Disponível em: <http:// www.ibge.gov.br/home/estatistica/economia/ppm/2008/defaulttabzip. shtm>. Acesso em: 02 fev. 2011. 
INSTITUTO DE DEFESA AGROPECUÁRIA E FLORESTAL DO ESPÍRITO SANTO. Legislação Estadual nº 4.781, de 14 de junho de 1993: regula a obrigatoriedade da prévia inspeção e fiscalização dos produtos de origem animal no Estado do Espírito Santo. Diário Oficial do Estado, Espírito Santo, 21 jun. 1993. Disponível em: <www.idaf. es.gov.br>. Acesso em: 30 ago. 2010.

LIMA, W. S. et al. Occurence of Fasciola hepatica (Linnaeus, 1758) infection in Brazilian cattle of Minas Gerais, Brazil. Revista Brasileira de Parasitologia Veterinária, v. 18, n. 2, p. 27-30, 2009.

MARQUES, S. M. T.; SCROFERNEKER, M. L. Fasciola hepatica infection in cattle and buffaloes in the State of Rio Grande do Sul, Brazil. Parasitologia Latino americana, v. 58, n. 3-4, p. 169-172, 2003.

MATTOS, M. J. et al. Ocorrência estacional de Lymnaea collumela Say, 1817 (Mollusca, Lymnaeidae) em habitat natural no Rio Grande do Sul. Revista Brasileira de Medicina Veterinária, v. 19, n. 6, p. 248-250, 1997.
MEDRONHO, R. A. et al. Epidemiologia. São Paulo: Atheneu, 2002. $493 \mathrm{p}$.

OAKLEY, G. A.; OWEN, B.; KNAPP, N. H. H. Production effects of subclinical liver fluke infection in growing dairy heifers. Veterinary Record, v. 104, n. 22, p. 503-507, 1979.

ROBINSON, M. W.; DALTON, J. P. Zoonotic helminth infections with particular emphasis on fasciolosis and other trematodiases. Philosophical Transactions of the Royal Society B, v. 364, n. 1530, p. 2763-2776, 2009.

SERRA-FREIRE, N. M. et al. Reinvestigação sobre a distribuição da Fasciola hepatica no Brasil. Hora Veterinária, v. 1, p. 19-21, 1995.

THRUSFIELD, M. Epidemiologia veterinária. 2. ed. São Paulo: Roca, 2004. 556 p. 